\title{
Penggunaan Google Form dalam Penilaian Harian Kimia di SMAN 6 Kota Serang pada Awal Pandemi Covid-19
}

\author{
Sonny Rohimat ${ }^{1 *}$ \\ ${ }^{1}$ SMA Negeri 6 Kota Serang, Banten \\ "E-mail: albaregbegi@gmail.com
}

\begin{abstract}
Abstrak
Kurikulum 2013 merupakan kurikulum berbasis kompetensi dengan menggunakan Kompetensi Dasar (KD) sebagai kompetensi minimum yang harus dicapai oleh peserta didik. Akan tetapi, pembelajaran pada semester genap tahun pelajaran 2019/2020 mengalami kendala akibat adanya wabah Covid-19, termasuk dalam pembelajaran di SMAN 6 Kota Serang. Untuk mengatasi masalah tersebut maka penilaian harian pada pembelajaran kimia di kelas XI MIPA 3 dilakukan secara daring dengan menggunakan aplikasi Google Form. Kegiatan yang dilakukan adalah menuntaskan proses pembelajaran KD 3.12 tentang larutan penyangga secara daring melalui Google Classroom, membuat instrumen penilaian, serta melaksanakan penilaian harian menggunakan Google Form. Pelaksanaan penilaian ini berlangsung dengan baik walaupun ada beberapa kendala dan kekurangan.
\end{abstract}

Kata Kunci: Covid-19, Google Form, Penilaian Harian Daring,.

\section{PENDAHULUAN}

Kurikulum 2013 merupakan kurikulum berbasis kompetensi dengan menggunakan Kompetensi Dasar (KD) sebagai kompetensi minimum yang harus dicapai oleh peserta didik. Untuk mengetahui ketercapaian KD, guru dituntut untuk merumuskan sejumlah indikator yang digunakan sebagai acuan penilaian. Selain itu sekolah juga harus menentukan kriteria ketuntasan minimal (KKM) untuk memutuskan seorang peserta didik sudah tuntas atau belum. Kriteria ketuntasan minimal ini perlu dievaluasi setiap tahun dan diharapkan secara bertahap mengalami peningkatan (Kemdikbud, 2017). Berdasarkan Peraturan menteri pendidikan dan kebudayaan nomor 23
Tahun 2016 Pasal 2 dinyatakan bahwa penilaian pada pendidikan dasar dan pendidikan menengah terdiri atas penilaian hasil belajar oleh pendidik; penilaian hasil belajar oleh satuan pendidikan; dan penilaian hasil belajar oleh pemerintah (Kemdikbud, 2016). Hal ini menunjukkan bahwa penilaian merupakan salah satu bagian penting dari proses pembelajaran.

Akan tetapi, pembelajaran pada semester genap tahun pelajaran 2019/ 2020 mengalami kendala. Kendala tersebut diakibatkan adanya wabah virus corona yang melanda hampir seluruh belahan dunia, termasuk Indonesia. Virus ini menyebar sangat cepat dan menimbulkan banyak korban meninggal dunia. 
Diantara langkah untuk mengurangi atau mempersempit penyebaran virus tersebut adalah dengan social distancing atau pembatasan sosial (Sanur, 2020).

Menteri Pendidikan dan Kebudayaan (Mendikbud) RI menerbitkan Surat Edaran Nomor 36962//MPK.A/HK/2020. Surat edaran tersebut berisi imbauan kepada lembaga pendidikan untuk melaksanakan pembelajaran secara daring (dalam jaringan) atau online dan bekerja dari rumah (Kemdikbud, 2020). Tujuan imbauan tersebut adalah untuk pencegahan penyebaran Corona Virus Disease (Covid-19). Di Provinsi Banten, masa pembelajaran di rumah yang awalnya direncanakan sampai tanggal 30 Maret 2020, secara resmi diperpanjang sampai tanggal 1 Juni 2020 dan terus dievaluasi sesuai dengan perkembangan kasus penyebaran yang terjadi. Hal tersebut tertuang dalam Instruksi Gubernur Banten Nomor 2 Tahun 2020 (Sekdaprov Banten, 2020).

Dengan kondisi tersebut, pembelajaran yang sedang berlangsung di sekolahsekolah, termasuk SMA Negeri 6 Kota Serang, harus menyesuaikan dengan surat edaran tersebut. Pembelajaran kimia di kelas XI MIPA 3 sedang membahas KD 3.12 yaitu "Menjelaskan prinsip kerja, perhitungan $\mathrm{pH}$, dan peran larutan penyangga dalam tubuh makhluk hidup". Materi pokok yang dibahas adalah tentang larutan penyangga. Materi lautan penyangga terdiri atas tiga submateri yaitu sifat larutan penyangga, perhitungan $\mathrm{pH}$ larutan penyangga, dan peranan larutan penyangga (Sutresna dkk, 2016). Pembahasan materi sudah hampir diselesaikan tetapi masih diperlukan adanya penilaian pengetahuan untuk KD tersebut.

Menurut Rizal (2018), salah satu sistem yang digunakan dalam pembelajaran daring adalah Learning Management System (LMS). Adapun aplikasi LMS yang banyak digunakan sebagai media pembelajaran daring adalah Google Classroom (Fauziah dkk, 2019). Pada awalnya pembelajaran daring di SMA Negeri 6 Kota Serang menggunakan media Whats App. Akan tetapi karena dianggap kurang efektif maka pihak sekolah memutuskan untuk menggunakan Google Classroom. Menurut Soni dkk. (2018), Google Classroom bisa memudahkan guru dalam mengelola tugas peserta didik tanpa menggunakan kertas. Peserta didik juga dapat belajar, menyimak, membaca, serta mengirim tugas dari jarak jauh.

Pelaksanaan penilaian harian untuk KD 3.12 tersebut harus memperhatikan surat edaran dari Mendikbud RI. Artinya, penilaian harus dilaksanakan secara daring. Bahkan penilaian harian secara daring juga bisa dilakukan pada kondisi normal untuk mengatasi kejenuhan peserta didik (Anggraini \& Ruwanto, 2017). Untuk itu diperlukan cara dan media yang bisa digunakan untuk melaksanakan penilaian tersebut secara daring juga. Salah satu aplikasi yang dapat digunakan dalam penilaian secara daring adalah Google Form yang terdapat pada Google Drive (Hamdani \& Kaburuan, 2017).

Google Form merupakan salah satu fitur yang terdapat pada Google Docs. Aplikasi ini sangat cocok untuk berbagai kalangan, 
termasuk guru, yang akan membuat berbagai pengumpulan data atau jawaban dari peserta didik. Google Form ini dapat dibagikan kepada peserta didik atau orang lain secara terbuka atau khusus kepada pemilik akun Google dengan pilihan aksesibilitas, sesuai kebutuhan. Selain itu, aplikasi ini juga dapat menjadi alternatif bagi orang-orang yang tidak memiliki dana untuk menggunakan program gratis daripada membajak program berbayar (Batubara, 2016).

Google Form merupakan salah satu aplikasi yang direkomendasikan untuk membuat alat penilaian secara daring. Tampilan dan cara pengunaanya cukup sederhana sehingga mudah dimengerti. Bahkan untuk penilaian dalam bentuk pilihan ganda, soal dan pilihan jawaban bisa diacak. Selain itu, kunci jawaban dan skor bisa diatur sehingga guru tidak perlu memeriksa satu per satu jawaban yang dikirim peserta didik. Dengan demikian, penggunaan Google Form hendaknya di optimalkan pada berbagai tugas pendidikan, seperti memberikan ulangan daring, mengumpulkan data siswa/guru, membuat formulir pendaftaran daring untuk sekolah, membagikan kuesioner kepada orang-orang secara daring dan mengumpulkan pendapat orang lain (Rahardja, 2018).

\section{METODE}

Penelitian ini merupakan penelitian kualitatif. Metode penelitian kualititatif merupakan suatu prosedur penelitian yang hasilnya berupa deskripsi (Siyoto \& Sodik, 2015) serta tidak dapat dicapai dengan menggunakan prosedur statistik
(Sidiq \& Choiri, 2019). Subyek penelitian ini adalah 36 peserta didik kelas XI MIPA 3 di SMA Negeri 6 Kota Serang tahun pelajaran 2019/2020. Penelitian dilakukan pada minggu keempat bulan Maret dan minggu pertama bulan April 2020. Penelitian dilakukan dalam pembelajaran kimia pada Kompetensi Dasar (KD) 3.12 dengan materi pokok larutan penyangga.

Penelitian dilakukan dalam dua tahap. Pertama, pendahuluan yaitu menuntaskan pembelajaran KD 3.12 dengan menggunakan moda daring. Kedua, pelaksanaan yaitu pembuatan instrumen dan pelaksanaan penilaian harian kimia pada materi pokok larutan penyangga. Tahapan penyusunan instrumen menurut Mukhlis dan Tohir (2019) meliputi penyusunan spesifikasi instrumen (tujuan, kisi-kisi, bentuk, dan panjang instrumen), penulisan soal instrumen, penelaahan (validasi ahli), dan perakitan soal instrumen. Akan tetapi dalam penyusunan instrumen penilaian harian ini seluruh tahapan dilakukan oleh peneliti sendiri, tidak melalui validasi ahli. Instrumen terdiri atas enam butir soal uraian. Dalam pengerjaan penilaian harian tersebut peserta didik diperbolehkan untuk membuka sumber belajar berupa buku atau laman internet (open book) tetapi diminta untuk tidak melakukan kerja sama.

\section{HASIL DAN PEMBAHASAN}

Sebelum pelaksanaan penilaian harian, kegiatan diawali dengan menuntaskan proses pembelajaran KD 3.12 tentang larutan penyangga. Dari tiga submateri, dua di antaranya sudah diselesaikan pada 
pembelajaran secara tatap muka, yaitu sifat larutan penyangga dan perhitungan $\mathrm{pH}$ larutan penyangga. Adapun submateri peranan larutan penyangga diselesaikan melalui pembelajaran secara daring.

Proses pembelajaran dilakukan melalui Google Classroom yang dikoordinasikan oleh Tim Kurikulum SMA Negeri 6 Kota Serang. Untuk mengawasi dan memudahkan koordinasi pembelajaran secara daring, Tim Kurikulum SMA Negeri 6 Kota Serang memasukkan seluruh guru dan peserta didik ke dalam Google Classroom. Dengan demikian, maka pembelajaran kimia KD 3.12 di kelas XI MIPA 3 dilakukan melalui Google Classroom.

Selanjutnya, guru memberikan informasi kepada peserta didik bahwa akan dilaksanakan penilaian harian secara daring. Informasi ini diperlukan agar peserta didik memiliki persiapan yang matang untuk mengikuti penilaian harian. Persiapan yang harus dilakukan oleh peserta didik terdiri atas persiapan materi pembelajaran dan persiapan sarana atau media. Persiapan materi pembelajaran yaitu KD 3.12 dengan materi pokok larutan penyangga. Persiapan sarana atau media berupa alat komunikasi berupa ponsel atau komputer/laptop serta jaringan internet yang memadai.

Tahap pelaksanaan dimulai dengan persiapan instrumen penilaian harian yang akan digunakan. Instrumen penilaian ini ditujukan untuk mengukur ranah pengetahuan pada KD 3.12 tentang larutan penyangga. Teknik yang digunakan pada penilaian harian ini berupa tes tertulis berbentuk soal-soal uraian. Instrumen penilaian ini terdiri atas enam soal uraian.

Setelah instrumen penilaian disiapkan, langkah selanjutnya adalah pembuatan formulir penilaian menggunakan Google Form. Langkah ini dimulai dengan masuk/ login ke akun google. Setelah masuk ke dalam akun google, pengguna disajikan berbagai fitur gratis dari google. Fiturfitur tersebut antara lain Telusuri, Maps, Youtube, Berita, Gmail, Kontak, Drive, Terjemahan, dan fitur-fitur lainnya.

Untuk membuat Google Form, fitur yang dipilih adalah Drive. Setelah memilih fitur Drive, pengguna akan masuk ke laman My Drive yang berisi berbagai data pengguna yang telah disimpan sebelumnya. Sedangkan untuk membuat Google Form yang baru maka pengguna bisa memilih tanda "New" di sebelah kiri atas. Kemudian pengguna memilih "More" dilanjutkan dengan memilih "Google Form". Sampai langkah tersebut, Google Form sudah siap untuk diatur sesuai kebutuhan.

Langkah selanjutnya adalah pengisian Google Form dengan berbagai pertanyaan atau soal yang dibutuhkan. Pada bagian atas, judul diganti menjadi "Kimia Larutan Penyangga (Buffer)". Untuk memperindah tampilan, di atas judul ditampilkan foto bagian depan SMA Negeri 6 Kota Serang. Adapun soal yang harus dijawab oleh peserta didik dibagi menjadi dua bagian. Bagian pertama adalah data diri peserta didik sedangkan bagian kedua adalah instrumen penilaian harian berupa soalsoal tentang larutan penyangga. Tampilan bagian pertama Google Form yang disajikan 
pada Gambar 1.

Pada bagian pertama, peserta didik wajib mengisi data secara lengkap sesuai dengan permintaan. Bentuk jawaban peserta didik disesuaikan dengan kebutuhan. Soal yang wajib diisi pada bagian ini adalah Kelas (Turun Naik), Absen (Isian Singkat), dan Nama (Isian Singkat).

Pada bagian kedua, Google Form diisi dengan instrumen peni-laian harian larutan penyangga. Cara pe-nulisan soal cukup dengan salin (copy) dan tempel (paste) dari instrumen yang sudah dibuat sebelumnya. Selain itu, soal bisa dilengkapi gambar yang dapat diunggah dari file yang sudah disiapkan. Karena soal yang digunakan adalah uraian, maka bentuk jawaban yang dipilih pada Google Form adalah Gugus Kalimat.

Jika pengisian

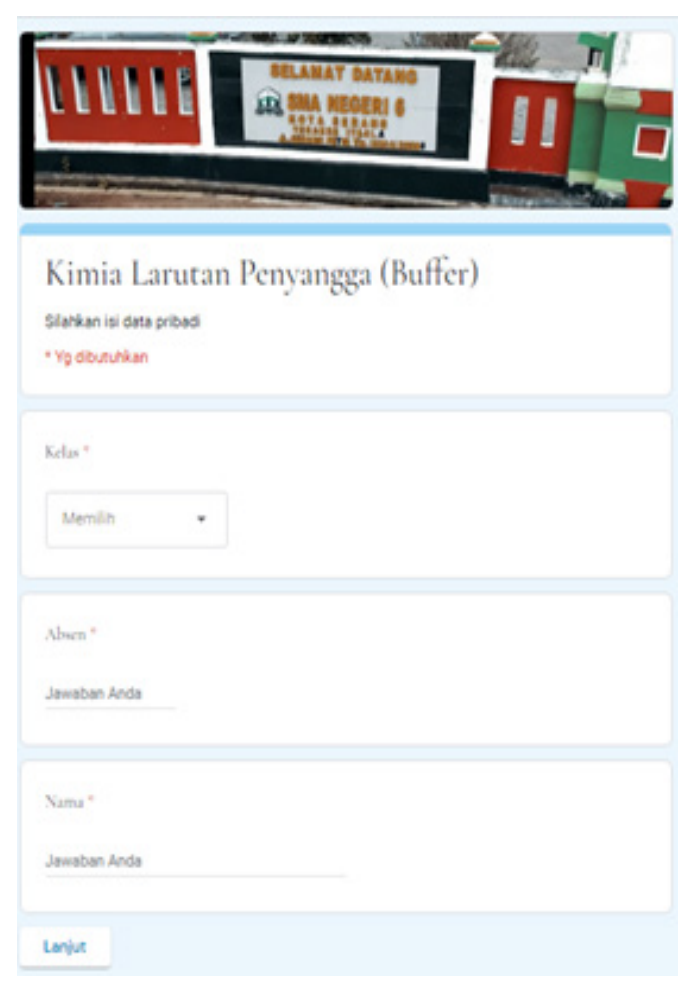

Gambar 1. Tampilan bagian pertama didik). Cara melakukan pratinjau adalah dengan menekan ikon mata di sebelah kanan atas. Jika instrumen sudah tidak ada lagi yang harus diperbaiki, maka Google Form sudah bisa dikirim. Pengiriman bisa dilakukan melalui surat elektronik (email), menyalin tautan (link), menyematkan HTML, atau dibagikan melalui facebook dan tweeter.

Pada pelaksanaan penilaian harian kimia KD 3.12 kelas XI MIPA 3 di SMA Negeri 6 Kota Serang, pengiriman Google Form dilakukan dengan cara menyalin tautan. Salinan tautan dikirimkan melalui Google Classroom yang telah difasilitasi oleh Tim Kurikulum SMA Negeri 6 Kota Serang. Pengiriman tautan Google Form ini dilaksanakan pada jam pelajaran kimia di kelas XI MIPA 3 yaitu pada hari Senin tanggal 6 April 2020 pukul 08.00 sampai dengan pukul instrumen penilaian sudah selesai, dapat 10.00 WIB. juga dilakukan pengaturan tampilan

Setelah instrumen penilaian dikirim, Google Form, pratinjau, dan disalin tautannya. Pengaturan (setting) dilakukan untuk mengatur pengumpulan email, pembatasan satu responden, akses responden, mengacak urutan soal, pesan konfirmasi, dan rilis nilai. Pratinjau (preview) dilakukan untuk melihat tampilan Google Form yang nantinya akan muncul dan dilihat responden (peserta maka guru memantau perkembangan peserta didik yang telah menyelesaikan pekerjaannya. Pada bagian ini guru sebagai pengguna Google Form bisa melihat ringkasan pekerjaan peserta didik sebagai responden, memberi umpan balik melalui email dengan menggunakan pengaya (add-on) pada Google Sheet, serta memeriksa jawaban peserta didik. 
Pemeriksaan jawaban peserta didik dapat dilakukan satu per satu secara daring atau mengunduh tanggapan, atau mencetak semua tanggapan pada Google Sheets.

Pelaksanaan penilaian harian kimia KD 3.12 kelas XI MIPA 3 di SMAN 6 berjalan dengan baik. Sebagian besar peserta didik menyelesaikan penilaian tanpa mengalami kendala yang berarti. Hal ini terlihat dari perkembangan penyelesaian soal-soal dengan relatif cepat. Peserta didik juga memahami maksud soal yang diberikan sehingga jawaban yang diberikan sesuai dengan pertanyaan yang diajukan.

Secara umum, aplikasi Google Form cocok digunakan untuk penilaian hasil belajar peserta didik. Aplikasi ini relatif mudah digunakan oleh guru dalam menuliskan berbagai bentuk soal, memantau perkembangan pengerjaan soal, serta memeriksa jawaban peserta didik. Bahkan untuk bentuk soal pilihan ganda, guru bisa langsung menentukan kunci jawaban dan poin tiap soal sehingga perolehan nilai peserta didik bisa langsung diketahui tanpa harus diperiksa secara manual. Selain itu, urutan soal dan pilihan jawaban juga bisa diacak. Aplikasi ini juga cukup mudah diakses oleh peserta didik dengan menggunakan komputer, laptop, ataupun ponsel android yang terhubung dengan jaringan internet.

Akan tetapi, pelaksanaan penilaian harian kimia kelas XI MIPA 3 ini juga memiliki beberapa kendala. Pertama, ada beberapa peserta didik yang terlambat dalam mengerjakan soal. Setelah dikomunikasikan dengan peserta didik diketahui bahwa hal ini terjadi karena ada peserta didik yang tidak memiliki ponsel android, tidak memiliki kuota (jaringan) internet, serta sinyal yang kurang baik. Kedua, peserta didik bisa membuka sumber belajar seperti buku atau laman internet ketika mengerjakan penilaian. Hal ini dikarenakan pengerjaan soal dilakukan dari rumah atau tempat lain yang tidak ditentukan sehingga tidak adanya pengawasan langsung dari guru saat peserta didik mengerjakan soal. Ketiga, ada indikasi kerja sama dalam pengerjaan soal. Hal ini terlihat dari adanya beberapa jawaban peserta didik yang persis sama. Kerja sama bisa dilakukan melalui alat komunikasi seperti ponsel dengan fasilitas telepon, aplikasi Whats App, dan lain sebagainya. Keempat, adanya kesulitan peserta didik dalam menuliskan jawaban karena keterbatasan fitur atau aplikasi pada alat (media) yang mereka gunakan.

\section{SIMPULAN}

Berdasarkan penelitian ini dapat disimpulkan bahwa Google Form merupakan salah satu aplikasi yang cocok digunakan dalam proses penilaian hasil belajar peserta didik. Bentuk soal yang dapat dipilih pada aplikasi tidak berbayar ini adalah plihan ganda, isian singkat, uraian, pilihan naik turun, dan unggah file. Agar pelaksanaan penilaian berjalan dengan baik maka peserta didik harus didukung dengan perangkat (ponsel android, komputer/laptop) serta jaringan internet yang memadai.

\section{DAFTAR PUSTAKA}

Anggraini, S. \& Ruwanto, B. (2017). Pengembangan Instrumen Penilaian Ulangan Harian Online untuk 
Mengukur Penguasaan Materi Fisika dan Mengetahui Respon Belajar Peserta Didik SMA. Jurnal Pendidikan Fisika, 6(2), 155-163. Retrieved from http:// journal.student.uny.ac.id/ojs/index. php/pfisika/article/view/7416/7057.

Batubara, H.H. (2016). Penggunaan Google Form sebagai Alat Penilaian Kinerja Dosen di Prodi PGMI Uniska Muhammad Arsyad Al Banjari. Al Bidayah, 8(1), 39-50. Retrieved from https://jurnal.albidayah.id/index.php/ home/article/view/91/88.

Fauziah, U.N.E., Suryani, L. \& Syahrizal, T. (2019). Penerapan Google Classroom dalam Pembelajaran Bahasa Inggris kepadaGuru-Guru Bahasa Inggris SMP di Subang. Jurnal Pengabdian Kepada Masyarakat, 02(02), 183-191. Retrieved from https://journal.ikipsiliwangi. ac.id/index.php/abdimas-siliwangi/ article/view/3281/830

Hamdani, Y. Y. \& Kaburuan, E. R. (2017). $G$ Suite. Bandung: Lembaga Sistem Informasi Universitas Informatika dan Bisnis Indonesia.

Kementerian Pendidikan dan Kebudayaan RI. (2016). Permendikbud nomor 23 Tahun 2016 tentang Standar Penilaian Pendididkan. Jakarta.

Kementerian Pendidikan dan Kebudayaan RI. (2017). Panduan Penilaian oleh Pendidik dan Satuan Pendidikan Sekolah Menengah Atas. Jakarta.

Kementerian Pendidikan dan Kebudayaan RI. (2020). Surat Edaran Menteri Pendidikan dan Kebudayan RI Nomor 36962//MPK.A/HK/2020 Perihal Pembelajaran secara Daring dan Bekerja dari Rumah dalam Rangka Pencegahan Penyebaran Corona Virus Disease (COVID- 19). Jakarta.

Mukhlis, M. \& Tohir, M. (2019). Instrumen Pengukur Creativity and Innovation Skills Siswa Sekolah Menengah di Era Revolusi Industri 4.0. Indonesian
Journal of Mathematics and Natural Science Education, 1(1), 65-73. Retrieved from https://mass.iain-jember.ac.id/ index.php/mass/article/view/1/12

Raharja, U., Lutfiani, N. \& Alpansuri, M.S. (2018). Pemanfaatan Google Formulir Sebagai Sistem Pendaftaran Anggota pada Website Aptisi.or.id. Jurnal Ilmiah SISFOTENIKA, 8(2), 128139. Retrieved from http://sisfotenika. stmikpontianak.ac.id/index.php/ST/ article/view/401/164

Rizal, S.A.S. (2018). Model Pembelajaran Dominan Online (Domon) di SMA Terbuka Kepanjen. Jurnal TEKNODIK, 22(1), 1-10. Retrieved from https:// jurnalteknodik.kemdikbud.go.id/ index.php/jurnalteknodik/article/ view/267/233.

Sanur, D. (2020). Wacana Kebijakan Lockdown dalam Menghadapi Covid-19 di Indonesia. Info Singkat, 12(6), 25-30. Retrieved from https:// berkas.dpr.go.id/puslit/files/info singkat/Info\%20Singkat-XII-6-II-P3DIMaret-2020-212.pdf

Sekretariat Daerah Provinsi Banten. (2020). Instruksi Gubernur Banten Nomor 2 Tahun 2020 tentang Perpanjangan Waktu Libur Proses Belajar Mengajar di Sekolah. Serang.

Sidiq, U. \& Choiri, M.M. (2019). Metode Penelitian Kualitatifdi Bidang Pendidikan. Ponorogo: Nata Karya.

Siyoto, S. \& Sodik, M.M. (2015). Dasar Metodologi Penelitian. Sleman: Literasi Media Publishing.

Soni dkk. (2018). Optimalisasi Pemanfaatan Google Classroom sebagai Media Pembelajaran di SMK Negeri 1 Bangkinang. Jurnal Pengabdian Untuk $\mathrm{Mu}$ NegeRI, 2(1), 17-20. Retrieved from https://ejurnal.umri.ac.id/ index.php/PengabdianUMRI/article/ view/361/352 
Indonesian Journal of Mathematics and Natural Science Education, 2 (1), 2021

Sonny Robimat

Sutresna, N., Sholehudin, D. \& Herlina, T. (2016). Aktif dan Kreatif Belajar Kimia 2. Bandung: Grafindo Media Pratama.

\section{PROFIL SINGKAT}

Penulis lahir di Ciamis tanggal 22 Oktober 1985, lulus dari Program Studi Pendidikan Kimia Universitas Pendidikan Indonesia pada tahun 2009. Tahun 2009-
2014 menjadi guru di SMKN 1 CidaunCianjur, dan sejak tahun 2014 sampai sekarang menjadi guru kimia di SMAN 6 Kota Serang - Banten. Saat ini penulis juga aktif sebagai Wakil Ketua Perkumpulan Pendidik Sains Kimia Indonesia (PPSKI) Provinsi Banten. 